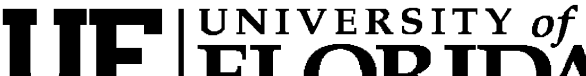 FLORIDA \\ IFAS Extension
}

\section{A Low Input, Sustainable Production System for Fresh Market Tomatoes ${ }^{1}$}

Jim Rich, Fred Rhoads and Steve Olson ${ }^{2}$

\section{Introduction}

Fresh market tomato is an important vegetable crop in Florida. During the 2006 season, the crop was grown on over 38,500 acres and was valued at over 551 million dollars. The production system, almost universally practiced by growers in Florida, is an intensively managed raised-bed system which includes soil fumigation, polyethylene mulch, drip or seepage irrigation, and stakes. This system produces yields that can exceed 20 tons/acre and has been widely used for over 40 years. Fumigation with a mixture of methyl bromide and chloropicrin has been a critical component of this production system and is relied upon for controlling soilborne diseases, nematodes, and weeds. However, methyl bromide is scheduled for total phase-out in the United States due to itspotential to deplete ozone.

With the impending loss of methyl bromide from Florida vegetable production systems, intensive efforts have been made by growers and scientists to develop methyl bromide alternatives, mainly in the form of soil-applied fumigants. Data from a series of tests conducted statewide have identified mixtures of 1,3-dichloropropene (Telone II) and chloropicrin as the most likely alternatives to methyl bromide for nematode and disease management. Limitations in soil-borne pest control with various alternatives, however, have included poor weed control and less than optimal nematode management for second crops.

An effective yet much overlooked soil and pest management practice in tomato production systems is rotation with perennial grasses (sod-based production systems). This practice predates the use of methyl bromide by many years. For example, watermelon growers traditionally sought bahiagrass sod fields which have lower levels of weeds, Fusarium wilt, and root-knot nematodes. In fact, this production system is still widely used in many southeastern production areas. Sod-based production systems with grasses such as bahiagrass not only reduce soil-borne pest and weed problems but are also known to provide nutrient recycling, improved soil tilth, organic matter, and increased water holding capacities.

1. This document is ENY-678 (EP128), one of a series of the Department of Entomology and Nematology, Florida Cooperative Extension Service, Institute of Food and Agricultural Sciences, University of Florida, Publication Date: February 2003. Revised: May 2008. Please visit the EDIS Web site at http://edis.ifas.ufl.edu.

2. Jim Rich, professor, North Florida REC, Entomology and Nematology Department, Fred Rhoads, professor, North Florida REC, Soil and Water Science Department, and Steve Olson, professor, North Florida REC, Horticultural Sciences Department, Cooperative Extension Service, Institute of Food and Agricultural Sciences, University of Florida, Gainesville, 32611.

The Institute of Food and Agricultural Sciences (IFAS) is an Equal Opportunity Institution authorized to provide research, educational information and other services only to individuals and institutions that function with non-discrimination with respect to race, creed, color, religion, age, disability, sex, sexual orientation, marital status, national origin, political opinions or affiliations. U.S. Department of Agriculture, Cooperative Extension Service, University of Florida, IFAS, Florida A. \& M. University Cooperative Extension Program, and Boards of County Commissioners Cooperating. Larry Arrington, Dean 
Plant resistance also is another important practice that can be used in pest management systems. During the development of the raised-bed production system, availability of plant disease resistance in tomato to nematode and soil-borne fungi was limited. However in subsequent years, both the range of resistance and incorporation of resistances into highly productive tomato varieties have increased dramatically. For example, a number of fresh market tomato varieties available in Florida now have resistance to Verticillium (race 1) and Fusarium wilts (races 1, 2, 3), and the three major root-knot nematode species. Due to pathogen adaptability, plant resistance is seldom recommended as a single control practice but rather used in an integrated management system consisting of rotation or chemicals.

With the horticultural improvements for disease resistance in tomatoes and the well-known record of sod-based systems, combinations of these two practices could prove adequate without use of fumigation in most Florida tomato production fields. This is particularly relevant with improved scouting and prediction methods. The utilization and testing of sod-based systems plus disease resistance in tomato, however, has been precluded by dependence on methyl bromide. Thus, little work has been conducted to determine either the merit or limitations of these two practices as replacements for methyl bromide. In the very least, these pest management practices could augment chemical alternatives that are replacing methyl bromide.

\section{A Strip Tillage System}

Ten field trails were conducted over five years on well established 'Pensacola' bahiagrass at the North Florida Research and Education Center, Quincy. Strip tillage was applied in bahiagrass sod and tomatoes subsequently transplanted into the strips. The main factors explored were: 1) sod management with mowing and herbicides; 2) strip tillage widths; 3) fertilizer rates; and 4) nematode and disease management. A summary of findings and observations from these trials are listed below.

\section{Cultural Practices and Weed Management}

The bahiagrass pasture chosen should be a solid stand at least three years old and have little weed growth. This period of time is required to establish a good stand of bahiagrass that does not contain weeds which may serve as hosts to plant disease and insect pests. Row spacings of four to six feet wide can be used since no bed is formed. In fact, closer row spacings have produced higher yields in our tests. Bahiagrass strips should be killed with glyphosate herbicide (sold as Roundup, Touchdown, Glyphomax, etc.) and then aggressively roto-tilled two months prior to transplanting. For spring plantings, the bahiagrass strips for tillage should be sprayed the previous fall. Strips should be a minimum of 24 inches wide and on 48" to 72" centers. After the initial tillage operations, pre-plant fertilizer can be applied and mixed into soil. For weed suppression and before transplanting, incorporate a recommended pre-plant herbicide such as metribuzin (Sencor) into the tilled strip. Under these conditions, weed management should be minimal with the exception of managing the bahiagrass growth in and between rows. To do so, mow the bahiagrass as needed and/or apply the herbicide sethoxydim (Poast) or clethodim (Select) at the recommended rate. This herbicide is used to stunt or reduce growth of the bahiagrass but generally does not kill the grass root systems. It is best used immediately before transplanting for row middles, and 4-7 wks after transplanting in rows and middles to stunt growth of the bahiagrass and reduce its competition for fertilizer.

A summary of studies evaluating tomato yield as influenced by sod growth management practices in middles are shown in Table 1. These data show that tomato yields in the 24- inch-wide tilled strips were superior to those in the 15 -inch-wide strips. Tomato yield in the mowed treatment with $180 \mathrm{lb} / \mathrm{A}$ of $\mathrm{N}$ and 24 inch tilled strips was almost twice that of the $1 / 2$ rate of Poast treatment with $180 \mathrm{lb} / \mathrm{A}$ of $\mathrm{N}$ and 15 inch tilled strips. The full rate of Poast and Gramoxone (paraquat) plus the 24 inch tilled strips gave highest yield with $180 \mathrm{lb} / \mathrm{A}$ of $\mathrm{N}$. However, there is a danger of damaging tomato plants with Gramoxone and using a third application of Poast to replace the Gramoxone may be as effective. 


\section{Fertilization}

As noted, it was found that bahiagrass was a competitor with the tomatoes for fertilizer and water. However, with methods described above, competition is limited and fertilizer management is similar to that of conventional systems. Fertilizer $\mathrm{N}_{2} \mathrm{P}_{2} \mathrm{O}_{5}$, and $\mathrm{K}_{2} \mathrm{O}$ recommendations for tomato from the Florida Agricultural Extension Service are shown in Table 2. A nitrogen rate of $200 \mathrm{lb} / \mathrm{A}$ is recommended for tomato in the raised bed, plastic mulch production system. In our tests, near maximum yields were obtained in strip-tilled tomato with180 lb/A of N where tilled strip width was 24 inches and sod growth in middles was adequately controlled (Table 1). Extension service soil test recommendations for tomato with very low levels of soil $\mathrm{P}$ and $\mathrm{K}$ are 150 $\mathrm{lb} / \mathrm{A}$ of $\mathrm{P}_{2} \mathrm{O}_{5}$ and $225 \mathrm{lb} / \mathrm{A}$ of $\mathrm{K}_{2} \mathrm{O}$. Strip-tilled tomato did not respond to $\mathrm{P}_{2} \mathrm{O}_{5}$ levels above 160 lb/A. A response of strip-tilled tomato to $\mathrm{K}_{2} \mathrm{O}$ levels between 130 and $260 \mathrm{lb} / \mathrm{A}$ was observed in only one of the field trials. Nitrogen, at the normal $200 \mathrm{lb}$ actual/acre rate, is recommended with application of $40 \%$ incorporated into the tilled strip before transplanting, and $10 \%$ per week through the drip system at 1, 2, 3, 4, 5, and 6 weeks after transplanting to minimize leaching and competitive uptake by the bahiagrass. Potassium should be applied through the drip system at $10 \%$ per week, $2,3,4,5$, and 6 weeks after transplanting also to minimize leaching and reduce competition from bahiagrass. All $\mathrm{P}_{2} 0_{5}, 50 \%$ of $\mathrm{K}_{2} \mathrm{O}$ and dolomite, if needed, should be incorporated into the strips before transplanting.

\section{Disease Management}

The use of tomato cultivars with multiple nematode and disease resistances is very important in both the conventional and the strip tillage system. In the field trial reported in Table 3, tomato exhibited good yields and no significant differences in yield or percent marketable fruit were found between a conventional fumigant treatment (Telone C-35) and the non-treated control. Significant differences in yield were observed among tomato varieties, but these were related to differing yield potentials of the varieties and resistance to tomato spotted wilt virus. Soil-borne fungal diseases were not detected in tomatoes and root galling caused by nematodes was not detected or at very low levels in the Telone C-35 or non-treated control plots. In those cases where root-galling was found, it was only present in tomato varieties without the Mi-gene resistance. These data show the importance of using varieties resistant to nematodes and other plant diseases since previously weedy spots in the bahiagrass could harbor pockets of root-knot nematodes and other disease-causing organisms. Additionally, tomato spotted wilt levels may be higher in strip till tomato production, thus use of cultivar resistance to TSW is important.

\section{Other Practices}

Other tomato production practices in the strip tillage system are similar to those used in raised-bed production. Normal pesticide application schedules are maintained, and tomato plants are staked. An insecticide for wireworms, cutworms and mole crickets may be necessary. In our tests, only mole crickets were a problem and in only one spring trial. An additional consideration is use of subsoiling in the planting row. Subsoiling not only increases rooting depth but also allows for easier and deeper stake placement. The amount of irrigation may need to be increased because of greater evaporation in the absence plastic mulch. Tensiometers installed in tilled strips between plants and observed daily will be valuable to help determine when to irrigate, the reading should be maintained below 20 centibars (cb). Tensiometers have a readable scale between 0 and $100 \mathrm{cb}$ with 0 being wet and 100 dry, the ideal range is 5 to 20. Plastic mulch application may be used in the strip-till system for soil warming and weed management. However, equipment will need to be modified or built for applying the mulch.

\section{Advantages}

The strip-till tomato production system offers many advantages compared to the conventional production system. The conventional raised-bed plastic mulch system creates conditions that favor the outbreak of many plant pests. Windblown soil created by bare row middles leads to plant injury, which increases foliar diseases. Rain splash dispersal of plant pathogens is increased on bare soil, and populations of key insect pests may be increased. Benefits of strip tillage into bahiagrass include 
reductions in production costs associated with land preparation, no fumigant costs, and reduced erosion due to storm water runoff. Sod-based rotation minimizes the increase of soil-borne pests and pesticide residue in the soil and reduces the effect of soil compaction due to repeated movement of heavy machinery over the same area. Limited but sound economic data show that grower profits can be increased using this strip tillage system due to fewer inputs required compared to the conventional tomato production system (Chellemi et al. 1999).

\section{Conclusion}

Over six million acres of bahiagrass are planted in Florida. This represents a largely untapped resource for Florida tomato growers and indeed other vegetable growers as well. The present strip-till system will allow for good tomato production and a quick return to grazing since the bahiagrass is not destroyed as in the conventional system. More research and farmer experience is needed to improve tomato production in the strip tillage system.

However, this system offers the potential for tomato production that is more environmentally sound and has the potential to help the industry remain competitive.

\section{References}

Chellemi, D. O., F. M. Rhoads, S. M. Olson, J. R. Rich, D. Murray, G. Murray, and D. M. Sylvia. 1999. An alternative, low input production system for fresh market tomato. American Journal of Alternative Agriculture 14:59-68.

Rhoads, F. M., S. M. Olson, J. R. Rich, and D. O. Chellemi. 1998. Strip-till tomato in bahiagrass: Management of fertility and grass in middles. Florida Agricultural Conference and Trade Show Proceedings pp. 38-41.

\section{Overview of Strip-Till Tomato Production}

1. The bahiagrass pasture chosen should be a solid stand at least 3 years old and have little weed

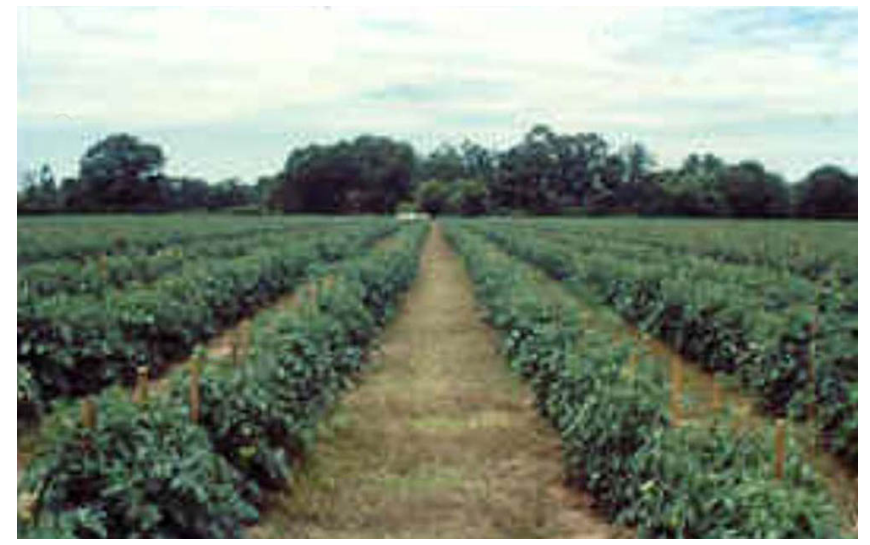

Figure 1. A large scale demonstration trial in a farmer's field.

growth. Four to six feet wide row spacings can be used since no bed is formed.

2. Bahiagrass strips 24 inches wide should be killed with glyphosate and then aggressively roto-tilled one month prior to transplanting. Strips should be killed in the fall four weeks before first frost for a spring crop and in early June for a fall crop.

3. Strip-till grass strips at least two months prior to transplanting. After the initial tillage operations and in-row subsoiling, apply pre-plant fertilizer and mix into soil.

4. Phosphorus, potassium and dolomite should be applied according to standard soil test recommendations. All phosphorus and dolomite should be applied to the tilled strip before transplanting. Fifty percent of potassium should be pre-plant incorporated and 50\% applied through the drip system at $10 \%$ per week, $2,3,4,5$, and 6 weeks after transplanting.

5. Before transplanting, shallowly incorporate a pre-plant herbicide such as Sencor into the tilled strip for weed suppression. To manage bahiagrass growth in and between rows, mow the bahiagrass as needed and apply the herbicide Poast at the recommended rate immediately before transplanting for row middles, and 4 and 7 weeks after transplanting in rows and middles to stunt growth of the bahiagrass.

6. Apply nitrogen, at the normal $180 \mathrm{lb}$ actual/acre rate with $40 \%$ pre-plant incorporated into the tilled strip, and $10 \%$ per week through the drip 
system at 1, 2, 3, 4, 5, and 6 weeks after

transplanting.

7. Use of tomato cultivars with multiple

nematode and disease resistances; Varieties with the most resistance would be labeled VFFNFcrSW ( $\mathrm{V}=$ Verticillum, $\mathrm{FF}=$ Fusarium races $1 \& 2$, $\mathrm{N}=$ Nematode, $\mathrm{Fcr}=$ Fusarium crown rot, $\mathrm{SW}=$ Spotted wilt).

8. Other tomato production practices in the strip-till system are similar to those used in the raised-bed system. Normal pesticide application schedules are maintained, and tomato plants are staked. An insecticide for wireworms, cutworms and mole crickets may be necessary.

9. The amount of irrigation, applied through a drip system to the tilled strip, needs to be monitored because of increased evaporation since plastic mulch is not used. Tensiometers installed in tilled strips between plants and observed daily will be valuable to help determine when to irrigate, the reading should be maintained below 20 centibars (cb).

10. Plastic mulch application may be applied in the strip-till system for soil warming and weed management. However, equipment will need to be modified or built for applying the mulch.

Table 1. Yield response of strip-till tomato in bahiagrass pasture to nitrogen $(\mathrm{N})$ rate and management of sod growth in middles.

\begin{tabular}{|c|c|c|c|}
\hline $\mathrm{N}$ rate in $\mathrm{Ib} / \mathrm{A}$ & $\begin{array}{l}\text { Width of tilled } \\
\text { strip-inches }\end{array}$ & Sod growth management in middles & $\begin{array}{c}\text { Yield in } \\
25 \mathrm{lb} \text {. Boxes/A }\end{array}$ \\
\hline $\begin{array}{l}180 \\
360 \\
\end{array}$ & 15 & $1 / 2$ rate of Poast $4 \& 6$ wks after transplanting & $\begin{array}{c}641 \\
1071^{*} \\
\end{array}$ \\
\hline $\begin{array}{l}180 \\
360 \\
\end{array}$ & 24 & Full rate of Poast $4 \& 6$ wks after transplanting & $\begin{array}{l}1133 \\
1265 \\
\end{array}$ \\
\hline $\begin{array}{l}180 \\
360 \\
\end{array}$ & 24 & Sod mowed as needed & $\begin{array}{c}1104 \\
1562^{*}\end{array}$ \\
\hline $\begin{array}{l}180 \\
360\end{array}$ & 24 & $\begin{array}{l}\text { Full rate of Poast preplant } \& 4 \text { wks after } \\
\text { transplanting plus Gramoxone } 9 \text { wks after } \\
\text { transplanting }\end{array}$ & $\begin{array}{l}1634 \\
1556\end{array}$ \\
\hline
\end{tabular}


A Low Input, Sustainable Production System for Fresh Market Tomatoes

Table 2. IFAS fertilizer recommendations for mineral soils for tomato on 6 -foot centers.

\begin{tabular}{|c|c|c|c|}
\hline \multirow[b]{2}{*}{ Soil-test level } & \multicolumn{3}{|c|}{ Fertilizer Recommendations in Ibs./A } \\
\hline & Nitrogen & $\mathrm{P}_{2} \mathrm{O}_{5}$ & $\mathrm{~K}_{2} \mathrm{O}$ \\
\hline Very High (VH) & 200 & 0 & 0 \\
\hline High $(H)$ & 200 & 0 & 0 \\
\hline Medium (M) & 200 & 100 & 100 \\
\hline Low (L) & 200 & 120 & 150 \\
\hline Very Low (VL) & 200 & 150 & 225 \\
\hline \multicolumn{4}{|c|}{$\begin{array}{l}\text { } \text { Olson, S.M., Stall, W.M., Momol, M. T., Webb, S. E., Taylor, T. G., Smith, S. A., Simmonne, E. H., McAvoy, E. } 200 \\
\text { Tomato production in Florida. In Olson, S. M. and Simonne, E ed. Vegetable production handbook for Florida. UF, } \\
\text { IFAS Extension. Chapter } 41 .\end{array}$} \\
\hline
\end{tabular}

Table 3. Tomato yield and percent marketable fruit in a field trial, utilizing bahiagrass sod, Telone C-35 and disease resistant varieties.

\begin{tabular}{|c|c|c|}
\hline Treatment & Yield, 25 lb. Boxes/A & $\%$ Marketable \\
\hline Telone C-35 & $1279 \mathrm{a}$ & $88.0 \mathrm{a}$ \\
\hline Control & $1303 \mathrm{a}$ & $89.4 \mathrm{a}$ \\
\hline BHN 577 (VFFNFerSW) & $1327 \mathrm{~b}$ & $91.5 \mathrm{a}$ \\
\hline BHN 543 (VFFN) & $1524 \mathrm{a}$ & $85.1 \mathrm{a}$ \\
\hline Solar Set (VFF) & $1459 a b$ & $88.9 \mathrm{a}$ \\
\hline Rutgers (none) & $852 \mathrm{c}$ & $88.7 \mathrm{a}$ \\
\hline
\end{tabular}

